\title{
Developmental Thyroid and Skeletal Muscle Dysfunction
}

\author{
Ahmed R.G* \\ Division of Anatomy and Embryology, Zoology Department, Faculty of Science, Beni-Suef University, Beni- \\ Suef, Egypt
}

*Corresponding Author: Ahmed R.G, Division of Anatomy and Embryology, Zoology Department, Faculty of Science, Beni-Suef University, Beni-Suef, Egypt, Email: ahmedragab08@gmail.com

\section{COMMENTARY}

Thyroid hormones (THs) are crucial for the standard development and thermo genesis (Elbakry et al., 2010; Ahmed, 2011, 2012a,b, 2013, 2014, 2015a-c, 2016a-d, 2017a-u, 2018a-f; Ahmed et al., 2008, 2010, 2012, 2013a,b, 2014, 2015a,b, 2018a,b; Ahmed and Ahmed, 2012; Ahmed and Incerpi, 2013;Van Hercket al., 2013; Ahmed and El-Gareib, 2014,Incerpi et al., 2014; Candelotti et al., 2015; De Vito et al., 2015; El-Ghareeb et al., 2016; Ahmed and ElGareib, 2017; Gigena et al., 2017; Bloise et al., 2018), particularly themyogenesis, contractile function, bioenergetic metabolism, the activity of the $\mathrm{Na}^{+}-\mathrm{K}^{+}$-ATPase in skeletal myotubes, the sarcoplasmic reticulum $\mathrm{Ca}^{2+}$-ATPase, the differentiation of muscle progenitor cell, and regeneration of the skeletal muscle (Dentice et al., 2010; Schiaffino and Reggiani, 2011; Salvatore et al., 2014; Ortiga-Carvalho et al., 2016; Boelen et al., 2017; Bloise et al., 2018).It is significant to notice that during the normal development of the skeletal muscle, the dynamic changes in the activities of THs can change the fiber type profile and the muscle propriety as well (Simonides and van Hardeveld, 2008; Schiaffino and Reggiani, 2011; Salvatore et al., 2014). In addition, the regular effect of hypothalamus-pituitary-thyroid axis (HPTA) on the homeostasis of the skeletal muscle depending on the thyroid receptors (TRs; $\alpha$ and $\beta$ ), thyroid transporters [monocarboxylate transporters (MCT8 and MCT10)] and thyroid metabolism enzymes (deiodinases; D2, D3) (D'Arezzo et al., 2004; Brockmann et al., 2005; Schwartz and Stevenson, 2007; Irrcher et al., 2008; Cordeiro et al., 2013; Di Cosmo et al., 2013; Boelen et al., 2017; Bloise et al., 2018). On the other hand, the acute, chronic or systemic inflammation can disturb this regulation and change the function of the skeletal muscle (Mebis et al., 2006; RodriguezPerez et al., 2008; Kwakkel et al., 2009; Fliers et al., 2014; Bloise et al., 2016; Van den Berghe, 2016). In addition, the expression of MCTs across the plasma membrane may depend on the type of inflammation (Bloise et al., 2018). Also, the disorders in thyroid function can cause the following: (1) reduce the metabolism and glucose level (Ahmed, 2013); (2)disrupt the activities of Ds (DIO2 activity and DIO3 mRNA) (Heemstra et al., 2009; Visser et al., 2009; Marsili et al., 2010;Louzada et al., 2014);(3)diaphragm muscle dysfunction (Herridge et al., 2003); (4) loss of muscle strength (Fredriksson et al., 2005); (5) muscle fatigue (Fredriksson et al., 2006); (6) diminish the mitochondrial content in both legs (Fredriksson and Rooyackers, 2007); (7) perturb the energy production in the respiratory muscle (Fredriksson et al., 2006; Fredriksson and Rooyackers, 2007; Zolfaghari et al., 2015); (8) change the nature of myosin in fast muscle (Butler-Browne et al., 1984; di Maso et al., 2000; Baldwin and Haddad, 2001; Bloise et al., 2018); and(9) muscle weakness and hypoplasia (Schwartz and Stevenson, 2007).

From the above aforementioned results, it can be established that the balance in HPTA may regulate the biological functions of the skeletal muscle. The disorders in the thyroid activity, TRs, Ds or MCTs may impact the myogenesis, the relaxation-contraction rates, metabolism and regeneration of the skeletal muscle. Additional considerations are necessary to confer the effect of thyroid disorders during the gestation on the fetal muscular physiological processes.

\section{REFERENCES}

[1] Ahmed, O.M., Abd El-Tawab, S.M., Ahmed, R.G., 2010. Effects of experimentally induced maternal hypothyroidism and hyperthyroidism on the development of rat offspring: I- The 
development of the thyroid hormonesneurotransmitters and adenosinergic system interactions. Int. J. Dev. Neurosci. 28, 437-454.

[2] Ahmed, O.M., Ahmed, R.G., 2012. Hypothyroidism. In A New Look At Hypothyroidism. Dr. D. Springer (Ed.), ISBN: 978-953-51-0020-1), In Tech Open Access Publisher, Chapter 1, pp. 1-20.

[3] Ahmed, O.M., Ahmed, R.G., El-Gareib, A.W., El-Bakry, A.M., Abd El-Tawaba, S.M., 2012. Effects of experimentally induced maternal hypothyroidism and hyperthyroidism on the development of rat offspring: II-The developmental pattern of neurons in relation to oxidative stress and antioxidant defense system. Int. J. Dev. Neurosci. 30, 517-537.

[4] Ahmed, O.M., El-Gareib, A.W., El-bakry, A.M., Abd El-Tawab, S.M., Ahmed, R.G., 2008. Thyroid hormones states and brain development interactions. Int. J. Dev. Neurosci. 26(2), 147-209. Review.

[5] Ahmed, R.G., 2011. Perinatal 2, 3, 7, 8tetrachlorodibenzo-p-dioxin exposure alters developmental neuroendocrine system. Food Chem. Toxicology, 49, 1276-1284.

[6] Ahmed, R.G., 2012a. Maternal-newborn thyroid dysfunction. In the Developmental Neuroendocrinology, pp. 1-369. Ed R.G. Ahmed. Germany: LAP LAMBERT Academic Publishing GmbH \& Co KG.

[7] Ahmed, R.G., 2012b. Maternal-fetal thyroid interactions, Thyroid Hormone, Dr. N.K. Agrawal (Ed.), ISBN: 978-953-51-0678-4, In Tech Open Access Publisher, Chapter 5, pp. 125-156.

[8] Ahmed, R.G., 2013. Early weaning PCB 95 exposure alters the neonatal endocrine system: thyroid adipokine dysfunction. J. Endocrinol. 219 (3), 205-215.

[9] Ahmed, R.G., 2014. Editorial: Do PCBs modify the thyroid-adipokine axis during development? Annals Thyroid Res. 1(1), 11-12.

[10] Ahmed, R.G., 2015a. Chapter 1: Hypothyroidism and brain development. In advances in hypothyroidism treatment. Avid Science Borsigstr.9, 10115 Berlin, Berlin, Germany. Avid Science Publications level 6, Melange Towers, Wing a, Hitec City, Hyderabad, Telangana, India. pp. 1-40.

[11] Ahmed, R.G., 2015b. Hypothyroidism and brain developmental players. Thyroid Research J. 8(2), 1-12.

[12] Ahmed, R.G., 2015c. Editorials and Commentary: Maternofetal thyroid action and brain development. J. of Advances in Biology; 7(1), 1207-1213.

[13] Ahmed, R.G., 2015d. Developmental adipokines and maternal obesity interactions. J. of Advances in Biology; 7(1), 1189-1206.
[14] Ahmed, R.G., 2016a. Maternal bisphenol A alters fetal endocrine system: Thyroid adipokine dysfunction. Food Chem. Toxicology, 95, 168-174.

[15] Ahmed, R.G., 2016b. Gestational dexamethasone alters fetal neuroendocrine axis. Toxicology Letters, 258, 46-54.

[16] Ahmed, R.G., 2016c. Maternal iodine deficiency and brain disorders. Endocrinol. Metab.Syndr.5, 223. http://dx.doi.org/10. 4172 / 2161-1017.1000223.

[17] Ahmed, R.G., 2016d. Neonatal polychlorinated biphenyls-induced endocrine dysfunction. Ann. Thyroid. Res. 2 (1), 34-35.

[18] Ahmed, R.G., 2017a. Developmental thyroid diseases and GABAergic dysfunction. EC Neurology 8.1, 02-04.

[19] Ahmed, R.G., 2017b. Hyperthyroidism and developmental dysfunction. Arch Med. 9, 4.

[20] Ahmed, R.G., 2017c. Anti-thyroid drugs may be at higher risk for perinatal thyroid disease. EC Pharmacology and Toxicology 4.4, 140142.

[21] Ahmed, R.G., 2017d. Perinatal hypothyroidism and cytoskeleton dysfunction. Endocrinol MetabSyndr 6, 271.doi:10.4172/2161-1017. 1000271

[22] Ahmed, R.G., 2017e.Developmental thyroid diseases and monoaminergic dysfunction. Advances in Applied Science Research 8(3), 01-10.

[23] Ahmed, R.G., 2017f.Hypothyroidism and brain development.J. Anim Res Nutr.2 (2), 13.

[24] Ahmed, R.G., 2017g. Antiepileptic drugs and developmental neuroendocrine dysfunction: Every why has A Wherefore. Arch Med 9(6), 2.

[25] Ahmed, R.G., 2017h. Gestational prooxidantantioxidant imbalance may be at higher risk for postpartum thyroid disease. Endocrinol MetabSyndr 6, 279.doi:10.4172/2161-1017. 1000279.

[26] Ahmed, R.G., 2017i. Synergistic actions of thyroid-adipokines axis during development. Endocrinol MetabSyndr 6, 280.doi:10.4172/ 2161-1017.1000280.

[27] Ahmed, R.G., 2017j. Thyroid-insulin dysfunction during development. International Journal of Research Studies in Zoology 3(4), 73-75. DOI: http://dx.doi.org/10.20431/2454941X.0304010.

[28] Ahmed, R.G., 2017k. Developmental thyroid diseases and cholinergic imbalance. International Journal of Research Studies in Zoology 3(4), 7072. DOI: http://dx.doi.org/10. 20431/2454941X.0304009.

[29] Ahmed, R.G., 20171. Thyroid diseases and developmental adenosinergic imbalance. Int $\mathbf{J}$ ClinEndocrinol 1(2), 053-055. 
[30] Ahmed, R.G., 2017m.Maternal anticancer drugs and fetal neuroendocrine dysfunction in experimental animals. Endocrinol MetabSyndr 6, 281.doi:10.4172/2161-1017.1000281.

[31] Ahmed, R.G., 2017n. Letter: Gestational dexamethasone may be at higher risk for thyroid disease developing peripartum. Open Journal Of Biomedical \& Life Sciences (Ojbili) 3(2), 01-06.

[32] Ahmed, R.G., 2017o.Deiodinases and developmental hypothyroidism. EC Nutrition 11.5, 183-185.

[33] Ahmed, R.G., 2017p.Maternofetal thyroid hormones and risk of diabetes. Int. J. of Res. Studies in Medical and Health Sciences 2(10), 1821.

[34] Ahmed, R.G., 2017r.Association between hypothyroidism and renal dysfunctions. International Journal of Research Studies in Medical and Health Sciences 2(11), 1-4.

[35] Ahmed, R.G., 2017s.Maternal hypothyroidism and lung dysfunction. International Journal of Research Studies in Medical and Health Sciences 2(11), 8-11.

[36] Ahmed, R.G., 2017t.Endocrine disruptors; possible mechanisms for inducing developmental disorders. International journal of basic science in medicine (IJBSM) 2(4), XX-Xx. (in press)

[37] Ahmed, R.G., 2017u.Maternal thyroid hormones trajectories and neonatal behavioral disorders. ARC Journal of Diabetes and Endocrinology 3(2), 18-21.

[38] Ahmed, R.G., 2018a. Maternal hypothyroidism and neonatal testicular dysfunction. International Journal of Research Studies in Medical and Health Sciences 3(1), 8-12.

[39] Ahmed, R.G., 2018b. Maternal thyroid disorders and bone maldevelopment: Are you ready to take risks for your offspring? J Pharma PharmaSci (JPPS) in press. DOI: 10.29011/2574-7711. 100058.

[40] Ahmed, R.G., 2018c. Non-genomic actions of thyroid hormones during development. App Clin Pharmacol Toxicol: ACPT-108. DOI: 10.29011/ACPT-109. 100008.

[41] Ahmed, R.G., 2018d. Maternal thyroid function and placental hemodynamics. ARC Journal of Animal and Veterinary Sciences 4(1), 9-13. DOI: $\quad$ http://dx.doi.org/10.20431/2455-2518. 0401002.

[42] Ahmed, R.G., 2018e.Interactions between thyroid and growth factors during development. ARC Journal of Diabetes and Endocrinology 4(1), 1-4. DOI: http://dx.doi.org/10.20431/ 2455-5983.0401001.

[43] Ahmed, R.G., 2018f.Genomic actions of thyroid hormones during development.ARC Journal of Diabetes and Endocrinology 4(1), 58. DOI: http://dx.doi.org/10.20431/2455-5983. 0401002 .
[44] Ahmed, R.G., Abdel-Latif, M., Ahmed F., 2015b.Protective effects of GM-CSF in experimental neonatal hypothyroidism. International Immunopharmacology 29, 538543.

[45] Ahmed, R.G., Abdel-Latif, M., Mahdi, E., ElNesr, K., 2015a. Immune stimulation improves endocrine and neural fetal outcomes in a model of maternofetal thyrotoxicosis. Int. Immunopharmacol. 29, 714-721.

[46] Ahmed, R.G., Davis, P.J., Davis, F.B., De Vito, P., Farias, R.N., Luly, P., Pedersen, J.Z., Incerpi, S., 2013b. Nongenomic actions of thyroid hormones: from basic research to clinical applications. An update. Immunology, Endocrine \& Metabolic Agents in Medicinal Chemistry, 13(1), 46-59.

[47] Ahmed, R.G., El-Gareib, A.W. 2014.Lactating PTU exposure: I- Alters thyroid-neural axis in neonatal cerebellum. Eur. J. of Biol. and Medical Sci. Res. 2(1), 1-16.

[48] Ahmed, R.G., El-Gareib, A.W., 2017.Maternal carbamazepine alters fetal neuroendocrinecytokines axis. Toxicology 382, 59-66.

[49] Ahmed, R.G., El-Gareib, A.W., Incerpi, S., 2014. Lactating PTU exposure: II- Alters thyroid-axis and prooxidant-antioxidant balance in neonatal cerebellum. Int. Res. J. of Natural Sciences 2(1), 1-20.

[50] Ahmed, R.G.,El-Gareib, A.W., Shaker, H.M., 2018a.Gestational 3,3',4,4',5pentachlorobiphenyl (PCB 126) exposure disrupts fetoplacental unit: Fetal thyroidcytokines dysfunction. Life Sciences 192, 213220.

[51] Ahmed, R.G., Incerpi, S., 2013. Gestational doxorubicin alters fetal thyroid-brain axis. Int. J. Devl. Neuroscience 31, 96-104.

[52] Ahmed, R.G., Incerpi, S., Ahmed, F., Gaber, A., 2013a. The developmental and physiological interactions between free radicals and antioxidant: Effect of environmental pollutants. J. of Natural Sci. Res. 3(13), 74-110.

[53] Ahmed, R.G.,Walaa G.H., Asmaa F.S., 2018b.Suppressive effects of neonatal bisphenol A on the neuroendocrine system. Toxicology and Industrial Health Journal (in press).

[54] Baldwin, K.M., Haddad, F., 2001.Effects of different activity and inactivity paradigms on myosin heavy chain gene expression in striated muscle. Journal of Applied Physiology 90, 345-357.

[55] Bloise, F.F., Cordeiro, A., Ortiga-Carvalho, T.M., 2018.Role of thyroid hormone in skeletal muscle physiology. Journal of Endocrinology 236, R57-R68.

[56] Bloise, F.F., van der Spek, A.H., Surovtseva, O.V., Ortiga-Carvalho, T.M., Fliers, E., Boelen, 
A., 2016. Differential effects of sepsis and chronic inflammation on diaphragm muscle fiber type, thyroid hormone metabolism, and mitochondrial function. Thyroid 26, 600-609.

[57] Boelen, A., van der Spek, A.H., Bloise, F., de Vries, E.M., Surovtseva, O.V., van Beeren, M., Ackermans, M.T., Kwakkel, J., Fliers, E., 2017. Tissue thyroid hormone metabolism is differentially regulated during illness in mice. Journal of Endocrinology 233, 25-36.

[58] Brockmann, K., Dumitrescu, A.M., Best, T.T., Hanefeld, F., Refetoff, S., 2005. X-linked paroxysmal dyskinesia and severe global retardation caused by defective MCT8 gene. Journal of Neurology 252, 663-666.

[59] Butler-Browne, G.S., Herlicoviez, D., Whalen, R.G., 1984. Effects of hypothyroidism on myosin isozyme transitions in developing rat muscle. FEBS Letters 166, 71-75.

[60] Candelotti, E., De Vito, P., Ahmed, R.G., Luly, P., Davis, P.J., Pedersen, J.Z., Lin, H-Y., Incerpi, I., 2015. Thyroid hormones crosstalk with growth factors: Old facts and new hypotheses. Immun., Endoc.\&Metab. Agents in Med. Chem., 15, 71-85.

[61] Cordeiro, A., Souza, L.L., Einicker-Lamas, M., Pazos-Moura, C.C., 2013. Non-classic thyroid hormone signaling involved in hepatic lipid metabolism. Journal of Endocrinology 216, R47-R57.

[62] D’Arezzo, S., Incerpi, S., Davis, F.B., Acconcia, F., Marino, M., Farias, R.N., Davis, P.J., 2004. Rapid nongenomic effects of 3, 5, 3 -triiodo-L-thyronine on the intracellular $\mathrm{pH}$ of L-6 myoblasts are mediated by intracellular calcium mobilization and kinase pathways. Endocrinology 145, 5694-5703.

[63] De Vito, P., Candelotti, E., Ahmed, R.G., Luly, P., Davis, P.J., Incerpi, S., Pedersen, J.Z., 2015.Role of thyroid hormones in insulin resistance and diabetes. Immun., Endoc. \& Metab. Agents in Med. Chem., 15, 86-93.

[64] Dentice, M., Marsili, A., Ambrosio, R., Guardiola, O., Sibilio, A., Paik, J.H., Minchiotti, G., DePinho, R.A., Fenzi, G., Larsen, P.R., et al., 2010. The FoxO3/ type 2 deiodinase pathway is required for normal mouse myogenesis and muscle regeneration. Journal of Clinical Investigation 120, 40214030.

[65] Di Cosmo, C., Liao, X.H., Ye, H., Ferrara, A.M., Weiss, R.E., Refetoff, S., Dumitrescu, A.M., 2013. Mct8-deficient mice have increased energy expenditure and reduced fat mass that is abrogated by normalization of serum T3 levels. Endocrinology 154, 48854895.

[66] diMaso, N.A., Caiozzo, V.J., Baldwin, K.M., 2000. Single-fiber myosin heavy chain polymorphism during postnatal development: modulation by hypothyroidism. American Journal of Physiology: Regulatory, Integrative and Comparative Physiology 278, R1099R1106.

[67] El-bakry, A.M., El-Ghareeb, A.W.,Ahmed, R.G., 2010.Comparative study of the effects of experimentally-induced hypothyroidism and hyperthyroidism in some brain regions in albino rats.Int. J. Dev. Neurosci. 28, 371-389.

[68] El-Ghareeb, A.A., El-Bakry, A.M., Ahmed, R.G., Gaber, A., 2016.Effects of zinc supplementation in neonatal hypothyroidism and cerebellar distortion induced by maternal carbimazole. Asian Journal of Applied Sciences 4(04), 1030-1040.

[69] Fliers, E., Kalsbeek, A., Boelen, A., 2014.Beyond the fixed setpoint of the hypothalamus-pituitary-thyroid axis.European Journal of Endocrinology 171, R197-R208.

[70] Fredriksson, K., Hammarqvist, F., Strigard, K., Hultenby, K., Ljungqvist, O., Wernerman, J., Rooyackers, O., 2006.Derangements in mitochondrial metabolism in intercostal and leg muscle of critically ill patients with sepsisinduced multiple organ failure. American Journal of Physiology: Endocrinology and Metabolism 291, E1044-E1050.

[71] Fredriksson, K., Radell, P., Eriksson, L.I., Hultenby, K., Rooyackers, O., 2005. Effect of prolonged mechanical ventilation on diaphragm muscle mitochondria in piglets. Acta Anaesthesiologica Scandinavica 49, 11011107.

[72] Fredriksson, K., Rooyackers, O., 2007. Mitochondrial function in sepsis: respiratory versus leg muscle. Critical Care Medicine 35, S449-S453.

[73] Gigena, N., Alamino, V.A., Montesinos, M.M., Nazar, M., Louzada, R.A., Wajner, S.M., Maia, A.L., Masini-Repiso, A.M., Carvalho, D.P., Cremaschi G.A., Pellizas, C.G., 2017.Dissecting thyroid hormone transport and metabolism in dendritic cells. J. Endocrinology 232, 337-350.

[74] Heemstra, K.A., Soeters, M.R., Fliers, E., Serlie, M.J., Burggraaf, J., van Doorn, M.B., van der Klaauw, A.A., Romijn, J.A., Smit, J.W., Corssmit, E.P., et al., 2009. Type 2 iodothyronine deiodinase in skeletal muscle: effects of hypothyroidism and fasting. Journal of Clinical Endocrinology and Metabolism 94, 2144-2150.

[75] Herridge, M.S., Cheung, A.M., Tansey, C.M., Matte-Martyn, A., Diaz-Granados, N., Al-Saidi, F., Cooper, A.B., Guest, C.B., Mazer, C.D., Mehta, S., et al., 2003. One-year outcomes in survivors of the acute respiratory distress syndrome. New England Journal of Medicine 348, 683-693.

[76] Incerpi, S., Hsieh, M-T., Lin, H-Y., Cheng, GY., De Vito, P., Fiore, A.M., Ahmed, R.G., 
Salvia, R., Candelotti, E., Leone, S., Luly, P., Pedersen, J.Z., Davis, F.B., Davis, P.J., 2014. Thyroid hormone inhibition in L6 myoblasts of IGF-I-mediated glucose uptake and proliferation: new roles for integrin $\alpha v \beta 3$. Am. J. Physiol. Cell Physiol. 307, C150-C161.

[77] Irrcher, I., Walkinshaw, D.R., Sheehan, T.E., Hood, D.A., 2008. Thyroid hormone (T3) rapidly activates p38 and AMPK in skeletal muscle in vivo. Journal of Applied Physiology 104, 178-185.

[78] Kwakkel, J., Chassande, O., van Beeren, H.C., Fliers, E., Wiersinga, W.M., Boelen, A., 2010. Thyroid hormone receptor $\{$ alpha\} modulates lipopolysaccharide-induced changes in peripheral thyroid hormone metabolism. Endocrinology 151, 1959-1969.

[79] Louzada, R.A., Santos, M.C., Cavalcanti-deAlbuquerque, J.P., Rangel, I.F., Ferreira, A.C., Galina, A., Werneck-de-Castro, J.P., Carvalho, D.P., 2014. Type 2 iodothyronine deiodinase is upregulated in rat slow- and fast-twitch skeletal muscle during cold exposure. American Journal of Physiology: Endocrinology and Metabolism 307, E1020-E1029

[80] Marsili, A., Ramadan, W., Harney, J.W., Mulcahey, M., Castroneves, L.A., Goemann, I.M., Wajner, S.M., Huang, S.A., Zavacki, A.M., Maia, A.L., et al., 2010. Type 2 iodothyronine deiodinase levels are higher in slow-twitch than fast-twitch mouse skeletal muscle and are increased in hypothyroidism. Endocrinology 151, 5952-5960.

[81] Mebis, L., Debaveye, Y., Visser, T.J., Van den Berghe, G., 2006. Changes within the thyroid axis during the course of critical illness. Endocrinology Metabolism Clinics of North America 35, 807-821.

[82] Ortiga-Carvalho, T.M., Chiamolera, M.I., Pazos-Moura, C.C., Wondisford, F.E., 2016.Hypothalamus-pituitary-thyroid axis. Comprehensive Physiology 6, 1387-1428.

[83] Rodriguez-Perez, A., Palos-Paz, F., Kaptein, E., Visser, T.J., Dominguez-Gerpe, L., AlvarezEscudero, J., Lado-Abeal, J., 2008. Identification of molecular mechanisms related to nonthyroidal illness syndrome in skeletal muscle and adipose tissue from patients with septic shock. Clinical Endocrinology 68, 821827.

[84] Salvatore, D., Simonides, W.S., Dentice, M., Zavacki, A.M., Larsen, P.R., 2014.Thyroid hormones and skeletal muscle - new insights and potential implications. Nature Reviews Endocrinology 10, 206-214.

[85] Schiaffino, S., Reggiani, C., 2011. Fiber types in mammalian skeletal muscles. Physiological Reviews 91, 1447-1531.

[86] Schwartz, C.E., Stevenson, R.E., 2007. The MCT8 thyroid hormone transporter and AllanHerndon-Dudley syndrome. Best Practice and Research Clinical Endocrinology and Metabolism 21 307-321.

[87] Simonides, W.S., van Hardeveld, C., 2008. Thyroid hormone as a determinant of metabolic and contractile phenotype of skeletal muscle. Thyroid 18, 205-216.

[88] Van den Berghe, G., 2016. On the neuroendocrinopathy of critical illness: perspectives for feeding and novel treatments. American Journal of Respiratory and Critical Care Medicine 194, 1337-1348.

[89] Van Herck, S.L.J., Geysens, S., Bald, E., Chwatko, G., Delezie, E., Dianati, E., Ahmed, R.G., Darras, V.M., 2013.Maternal transfer of methimazole and effects on thyroid hormone availability in embryonic tissues. Endocrinol. 218, 105-115.

[90] Visser, W.E., Heemstra, K.A., Swagemakers, S.M., Ozgür, Z., Corssmit, E.P., Burggraaf, J., van Ijcken, W.F., van der Spek, P.J., Smit, J.W., Visser, T.J., 2009. Physiological thyroid hormone levels regulate numerous skeletal muscle transcripts. Journal of Clinical Endocrinology and Metabolism 94 3487-3496.

[91] Zolfaghari, P.S., Carre, J.E., Parker, N., Curtin, N.A., Duchen, M.R., Singer, M., 2015. Skeletal muscle dysfunction is associated with derangements in mitochondrial bioenergetics (but not UCP3) in a rodent model of sepsis. American Journal of Physiology: Endocrinology and Metabolism 308, E713E725.

Citation: Ahmed R.G. Developmental Thyroid and Skeletal Muscle Dysfunction. ARC Journal of Diabetes and Endocrinology. 2018; 4(1):9-13. doi:dx.doi.org/10.20431/2455-5983.0401003.

Copyright: (c) 2018 Authors. This is an open-access article distributed under the terms of the Creative Commons Attribution License, which permits unrestricted use, distribution, and reproduction in any medium, provided the original author and source are credited. 